\title{
The role of unpasteurized "hawked" milk in the transmission of brucellosis in Eldoret municipality, Kenya
}

\author{
Augustine Taban Namanda ${ }^{1}$, Rose Kakai ${ }^{2}$, Mary Otsyula ${ }^{3}$ \\ ${ }^{1}$ Moi University, School of Public Health, P.O. Box 4606 - 30100, Eldoret, Kenya \\ ${ }^{2}$ Maseno University, School of Public Health and Community Development, P.O. Box 333 - 40105, Maseno, Kenya \\ ${ }^{3}$ Moi University, School of Science, P.O. Box 1125 - 30100, Eldoret, Kenya
}

\begin{abstract}
Background: Brucellosis is a zoonotic disease that continues to infect many people worldwide. Though its mortality rate is low, long convalescent periods associated with brucellosis translate into reduced socio-economic capacity of the people affected. Human brucellosis is mostly transmitted from animals. In Kenya, the prevalence of the disease has increased recently, along with the increased hawking of unpasteurized milk. The extent of the risk such raw milk poses to human health with respect to brucellosis is unknown. This study investigates the possibility of brucellosis being transmitted through unprocessed milk sold by hawkers in Eldoret municipality.

Methodology: In this cross-sectional study, 130 samples of unpasteurized pooled milk from hawkers and 14 pasteurized milk samples were collected from shops in selected estates using cluster and simple random sampling techniques. All samples were subjected to the Brucella Milk Ring Test (MRT) for screening. A milk consumption questionnaire was administered to households in the selected estates to establish their milk sources and consumption patterns. Data analysis involved comparing computed percentages of different variables. Results: A high proportion of households (77.5\%) consume unpasteurized milk from hawkers. However, no antibody to Brucella was detected in any of the milk samples collected.

Conclusion: We find no evidence that hawked milk in Eldoret is responsible for transmitting brucellosis to consumers. More research in the potential transmission of brucellosis through milk consumption is recommended.
\end{abstract}

Key words: brucellosis, pasteurization, transmission, hawking

J Infect Developing Countries 2009; 3(4):260-266.

Received 2 November 2008 - Accepted 17 March 2009

Copyright $(2009$ Namanda et al. This is an open-access article distributed under the Creative Commons Attribution License, which permits unrestricted use, distribution, and reproduction in any medium, provided the original work is properly cited.

\section{Introduction}

Brucellosis remains one of the world's most common public health problems [1]. Worldwide, more than 500,000 human cases of brucellosis are reported annually. This zoonotic disease is caused by various species of Brucella that infect many domestic animals, which act as reservoirs for human infection. The disease has evolved to establish itself as an occupational, as well as a food-borne, illness. The transmission of brucellosis through food ingestion is becoming more recognised in comparison to its occupational transmission, as less and less evidence associates it with occupational risks from exposure to organisms [2,3]. Probably for this reason, the disease is considered a re-emerging food-borne disease transmitted through contaminated raw milk and cheese [4]. Most milk is consumed in liquid form as compared to milk products. Despite the growing recognition of the importance of zoonoses in human health, these diseases are among the most neglected and poorly understood of all infectious diseases. Kenya has no vaccination policy on the control of brucellosis in either animals or humans. Some years ago, farmers opted to have their cattle vaccinated with $B$. abortus strain 19 , but the practice has declined due to the high vaccine costs. The vaccine remains useful at research and learning institutions. Decision-making is urgently required to determine the importance of brucellosis control relative to other public concerns and to select what brucellosis control strategies should be applied [5].

Many people may be at the risk of being infected with brucellosis because of their milk consumption habits. A study conducted on HIV patients in Nairobi, Kenya, with negative routine brucellosis microbiological culture had sera with large quantities of Brucella-specific IgM and IgG antibodies, suggesting a relatively high level of exposure to Brucella organisms in the cohort. This observation implies that brucellosis is probably under-diagnosed 
in Kenya. Brucella serology may be helpful in the diagnosis of patients with non-specific symptoms [7]. The purpose of this study was to determine the role of unpasteurized hawked milk in the transmission of brucellosis in the study area. This may guide strategies that can be used to prevent further transmission.

\section{Methods}

Study Area

Eldoret municipality and its surrounding areas are well known for milk production and are the main sources of hawked milk. Both large-scale and smallscale dairy farming contribute greatly to household income within these areas. This region is located in Uasin Gishu District, Rift Valley Province, in Kenya. In 1999, Eldoret municipality had an area of 147.9 $\mathrm{km}^{2}$. Its size has been increasing with time due to population pressure and business expansion. Spatial expansion of the municipality seems to follow the main roads radiating from the town. According to the 1999 Kenya National Census, Eldoret had a population of 197,449 people, with a growth rate of $4.9 \%$.

For the purpose of this study, the population of Eldoret was estimated to be 226,474 in the year 2002, assuming an annual population growth rate of $4.9 \%$ determined during the population census of 1999 . However, the actual population could be lower than this figure considering the socio-economic dynamics that have taken place. These include the collapse of the textile industry, which was a major employer for the inhabitants in Eldoret and may have contributed significantly to the population level at the time of the census. Many industry personnel who were laid off may have migrated out of the municipality since then. The town is mostly inhabited by people from different parts of the country who have come because of employment in both the private and public sectors. These people provide a market for both pasteurized and unpasteurized milk sold within the municipality.

\section{Study Population}

Unpasteurized milk hawkers and consumers of the hawked milk who are residents of Eldoret municipality comprise this population.

\section{Study Design}

This was a cross-sectional study based on samples of unpasteurized hawked milk and pasteurized packaged milk from the local market.
Administration of the household milk consumption questionnaire also features the cross-sectional design.

\section{Sample Size}

The sampling period was set for June to September 2004. Samples that satisfied the inclusion criteria during the study period were included. A total of 130 samples from milk hawkers and 14 packaged milk samples from shops were collected across the town. Up to 200 households distributed equitably in the estates of Eldoret were sampled as respondents to the household milk consumption questionnaire.

\section{Inclusion Criteria}

The following criteria were used to justify inclusion of samples and households responding to the questionnaire:

1. Samples were from selected estates only.

2. Samples were from milk presented for sale.

3. Samples were handled in the same way as the milk which is sold to consumers prior to their collection.

4. Pasteurized milk was obtained from the same area and time as the hawked milk samples.

5. Respondents to the household milk consumption questionnaire were immediate family members (father, mother or children), aged 18 years and above, from households belonging to the selected estates.

\section{Sampling Procedure}

The study used the cluster sampling technique, in which the population of Eldoret was divided into four clusters based on relative positions of the estates to the town centre. Clusters were comprised of estates to the South, West, North and Town centre (Table 1). From each cluster, estates were listed and milk hawking points identified. Hawking points and hawkers to supply the samples from each estate were identified by simple random selection. Where the milk hawkers in a selected hawking point did not have milk on a particular day, the nearest hawking point was selected as an alternative. Apart from supplying the milk samples, hawkers were requested to provide information for the samples they supplied, including the milk's area of origin. This information was recorded by sample code, but it was not disclosed to the laboratory technician who performed the tests.

One packaged pasteurised milk sample was bought from a shop at each selected estate or cluster, removed from the packet and put in a container 
similar to those that the unpasteurized milk samples were placed in, and then coded before being carried to the laboratory. These processes ensured adequate blinding in sample handling at the laboratory.

\section{Milk Sample Collection and Transportation}

Hawked milk samples were collected three days every week. After hawkers gave their informed consent, half-litre milk samples were purchased in the paper bags that consumers used. Each day that milk samples were collected, a half-litre sample of packaged pasteurized milk was also bought from a shop in the same locality and subjected to the same laboratory treatment as the hawked milk samples.

All milk samples were immediately placed in sterile paper bags similar to the ones milk is sold in to ensure the same conditions in which hawked milk is sold to consumers. Samples were coded with identification stickers, immediately placed in vaccine carriers with ice packs to prevent decomposition, and transported to Veterinary Investigation Laboratories (VIL) in Eldoret where they were temporarily stored in the refrigerator, awaiting onward transportation to Analabs in Nairobi.

\section{Processing of Samples for Laboratory Investigation}

At the VIL laboratory, $10 \mathrm{ml}$ of milk was taken from each sample using small sterile measuring cylinders and placed in sterile test tubes, which were sealed with stoppers, labelled with their corresponding sample codes, and temporarily stored in a refrigerator at $0-4^{\circ} \mathrm{C}$. Within 12 hours, these were transported in a vaccine carrier with ice packs to Analabs for processing. After removing the 10-ml samples, the remaining milk was discarded.

\section{Laboratory Analysis of Milk Samples}

At Analabs, the "Brucella Milk Ring Test" (MRT) was performed to screen each milk sample for Brucella antibody. Milk samples were stored overnight at $4^{\circ} \mathrm{C}$ before testing, according to the procedure described by Collins et al. [8]. During testing, one $\mathrm{ml}$ of the well-mixed raw milk stored overnight was placed in a narrow wintrobe tube, to which one drop of the stained antigen (milk ring test reagent) was added using sterile droppers. These were immediately mixed by inverting the wintrobe tubes several times. Placed on small test-tube racks, the tubes were allowed to stand for one hour at $37^{\circ} \mathrm{C}$ in a water bath before observation. If Brucella antibodies were present in milk, they would react with homologous antigens in the test reagent and result in agglutination. Stained aggregates of the Brucella bacilli would rise with the cream, giving a blue cream line above a white column of milk. A weak positive would show a blue cream line and a blue colour in the milk. If no antibodies were present, a white cream line would appear above the normal white milk column. Positive and negative controls were included for each test.

\section{Interviews of Milk Hawkers and Household Respondents}

Each milk hawker from whom milk samples were collected was requested to give information on where the milk originated, who their customers were, and what they knew about the use of the milk by their customers. This information was recorded by sample code on a check list form.

A household milk consumption questionnaire was administered to capture information relating to use and sources of their milk, any health complications encountered as a result of milk consumption, and the occupation of those affected.

\section{Data Analysis}

Data was entered into the computer-based Statistical Package for Social Scientists (SPSS, version 11) and analysed for frequencies and percentages.

\section{Ethical Considerations}

Approval to conduct this study was sought from the Institutional Research and Ethics Committee (IREC) at the faculty of Health Sciences, Moi University. Verbal informed consent was obtained from the hawkers and household consumers before being included in the study. All information was kept confidential.

\section{Results}

Brucella Antibody in Unpasteurized and Pasteurized Milk

As indicated in Table 2, there was no positive reaction between the MRT and all milk samples. These results show that the sampled milk did not have Brucella antibodies.

\section{Consumers of Hawked Milk}

Over $99 \%$ of hawkers sampled (129/130) sold milk to households, and $10 \%$ of milk hawkers $(13 / 130)$ sold to hotels. Thus $9.2 \%$ of the hawkers (12/130) sold milk to both hotels and household 
Table 1. Number of milk samples collected per culture estates

\begin{tabular}{|c|c|c|c|c|c|c|}
\hline Cluster & Description & Estate & $\begin{array}{l}\text { No. } \\
\text { points }\end{array}$ & of hav & \multicolumn{2}{|c|}{$\begin{array}{l}\text { No. (\%) of } \\
\text { collected }\end{array}$} \\
\hline \multirow[t]{3}{*}{1} & \multirow{3}{*}{$\begin{array}{l}\text { South of the Town } \\
\text { River Sosiani) }\end{array}$} & (South of Hill School & 15 & $(3.9)$ & 3 & $(2.1)$ \\
\hline & & Kipkaren & 36 & $(9.3)$ & 24 & (16.7) \\
\hline & & Langas & 44 & $(11.3)$ & 29 & $(20.1)$ \\
\hline \multirow[t]{13}{*}{2} & \multirow[t]{13}{*}{ West of the Town } & Bacon & 14 & (3.6) & 4 & $(2.8)$ \\
\hline & & Boma & 14 & $(3.6)$ & 4 & $(2.8)$ \\
\hline & & Bondeni & 21 & $(5.4)$ & 7 & $(4.9)$ \\
\hline & & Bridge Camp & 7 & $(1.8)$ & 2 & (1.4) \\
\hline & & Hurruma & 42 & $(10.8)$ & 14 & $(9.7)$ \\
\hline & & Kahoya & 14 & $(3.6)$ & 4 & $(2.8)$ \\
\hline & & Kidiwa & 15 & $(3.9))$ & 2 & $(1.4)$ \\
\hline & & Mwanzo & 10 & $(2.6)$ & 3 & $(2.1)$ \\
\hline & & Road Block & 10 & $(2.6)$ & 3 & $(2.1)$ \\
\hline & & Komongo & 10 & $(2.6)$ & 3 & $(2.1)$ \\
\hline & & Keroka & 3 & $(0.8)$ & 1 & $(0.7)$ \\
\hline & & Mwenderi & 14 & (3.6) & 4 & $(2.8)$ \\
\hline & & Shauri & 7 & $(1.8)$ & 2 & $(1.4)$ \\
\hline \multirow[t]{6}{*}{3} & \multirow[t]{6}{*}{ North of the Town } & Forest & 8 & $(2.1)$ & 1 & $(0.7)$ \\
\hline & & \begin{tabular}{|l} 
Jerusalem \\
\end{tabular} & 10 & $(2.6)$ & 4 & $(2.8)$ \\
\hline & & Kapsoya & 14 & (3.6) & 5 & $(3.5)$ \\
\hline & & Kimumu & 14 & $(3.6)$ & 5 & $(3.5)$ \\
\hline & & Munyaka & 15 & $(3.9)$ & 5 & $(3.5)$ \\
\hline & & Prisons & 9 & $(2.3)$ & 1 & $(0.7)$ \\
\hline \multirow[t]{2}{*}{4} & \multirow[t]{2}{*}{ Town centre } & Kampi Somali & 11 & $(2.8)$ & 4 & $(2.8)$ \\
\hline & & CBD* & 31 & $(8.0)$ & 10 & $(6.9)$ \\
\hline \multicolumn{2}{|c|}{ Grand Total } & 24 & 388 & 100 & 144 & 100 \\
\hline \multicolumn{2}{|l|}{ Mean } & & 16.2 & 4.2 & 6.0 & 4.2 \\
\hline \multicolumn{2}{|c|}{ Standard deviation } & & 10.9 & 2.8 & 7.0 & 4.8 \\
\hline
\end{tabular}

Table 2. Results of Brucella antibody by MRT analysis

\begin{tabular}{|l|l|l|l|}
\hline \multirow{2}{*}{ MRT results } & \multicolumn{2}{|l|}{ Number (\%) of milk samples: } & \multirow{2}{*}{ Total } \\
\cline { 2 - 3 } & Unpasteurized & Pasteurized & \\
\hline Positive & 0 & 0 & 0 \\
\hline Weak positive & 0 & 0 & 0 \\
\hline Negative & $130(100)$ & $14(100)$ & 144 \\
\hline Total & $\mathbf{1 3 0}$ & $\mathbf{1 4}$ & $\mathbf{1 4 4}$ \\
\hline
\end{tabular}

clients, while only $0.8 \%$ of hawkers (1/130) reported to have only hotel customers. Hawkers' perception of milk use by their customers was as follows: of the 130 hawkers interviewed, $110(84.6 \%)$ said the milk was used for unspecified domestic purposes, 20 (15.4\%) said it was for making household tea, and 14 $(10.8 \%)$ said it was for hotel tea. Domestic milk use may also include making tea for households.

\section{Hawkers' Sources of Milk}

Hawkers were supplied with milk by middlemen from different places both within and outside Uasin Gishu district (Fig. 1). Milk was delivered in the

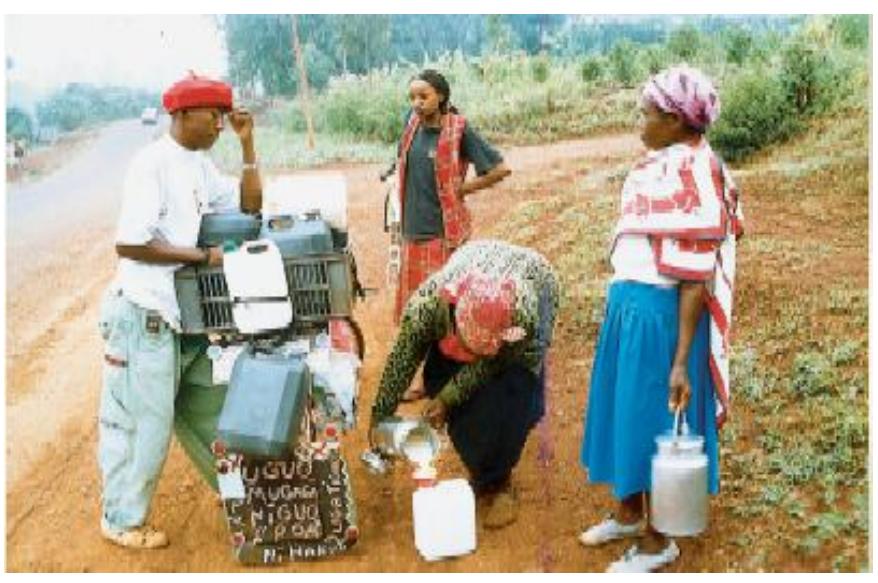

Figure 1. Unpasteurized milk hawkers and a middle-man. 
morning to the hawking points, from which the consumers could access it the whole day.

Most of the milk was supplied to hawkers through middlemen from Ndalat $(17.7 \%)$ and Tanning $(17.7 \%)$ in Eldoret, followed by Soy $(11.5 \%)$ and Kapsabet $(8.5 \%)$ about $40 \mathrm{~km}$ away on the outskirts of Eldoret town. Outside Uasin Gishu District, milk was supplied to hawkers from as far away as Trans Nzoia, Keiyo, Eldama Ravine, and Nandi North districts.

\section{Sources and Uses of Household Milk}

Selected in proportions corresponding to the number of milk samples and the population of each estate, 200 respondents from Eldoret estates were interviewed. Langas (19.5\%) had the highest number of respondents, followed by Kipkaren (16\%) and Huruma (14\%). The lowest number of respondents was $1(0.8 \%)$ each for Forest, Kamukunji, Keroka and Prisons.

Out of the 200 respondents, 99\% reported that they used either packaged or unpasteurized milk, while only $2 / 200(1 \%)$ did not use any milk in their households. Three sources of milk were named by respondents: packaged milk from shops or kiosks, unpackaged milk from hawkers, and milk from the respondents' own cows. Among the 198 households that used milk, the majority $(84.8 \%)$ obtained it from only one source, $9.6 \%$ from two sources, and 5.6\% from three sources. Only 51/200 (25.5\%) respondents owned cows from which they received milk at one time or another. Thus a large proportion of the population $(74.5 \%)$ relied on other sources for their milk supply. At the time of the study, out of the 200 respondents, $155 \quad(77.5 \%)$ used hawked unpasteurized milk, while $45(22.5 \%)$ did not. Thirty respondents gave reasons for preferring the commonly used hawked milk sources. These included affordability and accessibility (66.7\%), hygienic properties (20\%), large family (6.7\%), allergy to other sources (3.3\%), and lack of other alternatives $(3.3 \%)$.

Respondents reported that their households used milk for one or more domestic purposes. Making tea was the predominant use, reported by 194 respondents $(97 \%)$. This was followed by feeding children, reported by 64 respondents (32\%); making fermented milk (mala), reported by 35 respondents $(17.5 \%)$; and drinking milk the way it was bought, reported by only 25 respondents $(12.5 \%)$ who did not specify the source of such milk directly consumed.
Health Complications Related to Milk Consumption

According to the perception of the respondents, $10 / 200(5 \%)$ reported that their households' members had suffered complications related to milk consumption while the remaining 190 (95\%) did not report complications. These were general complications which included three reports of diarrhoea (30\%), two reports of vomiting and diarrhoea (20\%), two reports of allergy (20\%), two reports of brucellosis (20\%), and one report of stomach upsets $(10 \%)$. Eight $(80 \%)$ respondents reported that only one member of the household had suffered complications, while the remaining two households reported that two $(10 \%)$ or three $(10 \%)$ household members suffered complications.

One hundred and sixty five respondents $(82.5 \%)$ knew about brucellosis, while 35 (17.5\%) did not. Among respondents who knew about brucellosis, 13 (7.9\%) knew of a household member, neighbour, or themselves who had suffered from the disease. Out of these, the occupation of people whom they knew had suffered from brucellosis was that of housewife in eight cases $(61.5 \%)$, a student in two cases $(15.4 \%)$, farmer in two cases (15.4\%), and shopkeeper in one case $(7.7 \%)$. Thus the disease seems to be more common among housewives.

\section{Discussion}

Brucellae are among the many pathogenic microorganisms that are spread through milk of infected animals, and they can occasionally be detected in milk and milk products $[9,10]$. Other studies have shown that there appears to be a positive correlation between the prevalence of brucellosis in animals and in humans [11]. In Kenya, according to monthly reports from the Trans-Nzoia district veterinary office, the average case prevalence rate for bovine brucellosis was among the top ten cattle diseases with $8.5 \%$ prevalence. Consumption of raw or unpasteurized milk can be a source of human infection [12]. Other sources of infection may include direct contact with contaminated milk or carcasses, consumption of improperly cooked meat from infected carcasses, or handling of milk that is sold directly by farmers to consumers without going through the hawking channel. In spite of its potential to transmit brucellosis, milk is one of the animal products consumed by many families, most of whom are not producers of the commodity, especially those residing in towns and urban centres [13]. In our study, a majority (77.5\%) of the households used unpasteurized milk sold by hawkers. The peri-urban 
areas and parts of Eldoret municipality are known for milk production. Inhabitants of the town provide a ready market for both processed and unprocessed milk sold within the municipality.

Whereas the market for crop products has been consistent, that of milk has been on the downward trend, especially after the collapse of the Kenya Cooperative Creameries (KCC) in the early 1990s. This left the dairy farmers and especially the small scale milk producers to resort to alternative milk marketing strategies such as hawking, middlemen and independent milk processors. This was also the time when inflation rate was highest in the country, with price increases being felt on all other commodities required by households. These multiple factors encouraged consumers who may have found this source relatively cheaper than processed milk. Convenient delivery and lower prices are the principal benefits for poor consumers [13]. In this study, most of the clients were household consumers, $67 \%$ of whom preferred hawked milk because it was affordable and available.

About $56 \%$ of milk produced by small holder farmers is sold raw in an unregulated informal market; both the product and delivery method raise public health concerns about its purity and safety (14). Since milk from different sources is usually pooled together by hawkers, one source may contaminate all the milk in the pool. Eldoret municipality is one of the towns in Kenya where hawking of unpasteurized milk and its products, especially fermented milk ("mala") is common, probably exposing its residents to milk-borne zoonotic diseases such as brucellosis. According to the local people's perception, brucellosis has become a disease of great public health concern in this area and its transmission is to a great extent linked to the consumption of hawked milk. In Kenya, there have been no meaningful epidemiological studies conducted on human brucellosis, but evidence from anecdotal reports showed that the disease is common among pastoralists in Narok district with a prevalence of $13.7 \%$ (15). Agglutinin for Brucellae antigens in blood sera among healthy people in Nairobi and Naivasha was $4 \%$ and $7 \%$ reactivity, respectively [16]. The reactivity among participants from Naivasha was associated with high contact with unsterilized milk as compared to those from Nairobi. Mosoriot health facility on the outskirts of Eldoret recorded a prevalence rate of $35 \%$ by Brucella test [17]. Records at a local hospital in Eldoret show that in a month, an average of 40/174 (23\%) requests for laboratory confirmation are brucellosis positive, indicating the necessity of organizing epidemiologic surveillance on brucellosis [18].

Knowledge of brucellosis among respondents was high. This may have contributed to the absence of antibodies from the milk. In Saudi Arabia, 79\% of patients with acute brucellosis who were admitted at the King Fayad National Hospital were illiterate [19]. About $97 \%$ of the consumers used milk for making tea, a process that subjects the milk to high temperatures and destroys most of the inherent microorganisms, including Brucella species. A study carried out in Nakuru and Narok within Kenya revealed that $96 \%$ of rural milk consumers boiled milk either in tea or otherwise prior to consumption $[13,20]$. It is possible that hawkers also boil the milk before sale in order to extend its shelf-life. Regarding association of brucellosis with occupation, housewives seemed to be the most affected. Transmission through contact can be associated with one's occupation. It was not stated what roles the housewives were carrying out that exposed them to risk of brucellosis infection. Probably they were directly involved in activities such as milking cows and tea preparation in which they are likely to come into direct contact with Brucellae contaminated milk.

The Milk Ring Test (MRT) is a reliable means of screening herds of cattle for Brucella organisms [21]. Pooling of milk from Brucella infected and clean herds has a dilution effect that could reduce the concentration of antibodies in the milk to undetectable levels. It is not clear if this had an effect on the results of this study. Previous studies in rural and urban areas of Nakuru, Narok, Nairobi, and Kiambu detected 3-5\% of Brucella antibodies from samples drawn at both consumer households and markets using MRT and enzyme-linked immunosorbent assay (ELISA) [22,23]. In this study, no antibody was detected by MRT from any of the milk samples. It is therefore concluded that there is no evidence to suggest that unpasteurized milk sold in Eldoret by hawkers is responsible for transmission of human brucellosis. Further studies are recommended to perform culture and/or ELISA testing concurrently with MRT when examining milk, or to screen livestock herds to identify the source, so as to control the disease in animals, and ultimately among human populations.

\section{Acknowledgements}


We wish to convey our thanks to the Southern Sudan Programme of the Agency for Cooperation and Research in Development (ACORD) for financial assistance. We thank the Director of Veterinary Services (Kabete), Officer in charge of Veterinary Investigation Laboratories (Eldoret) and staff of Analabs (Nairobi), for use of their facilities.

\section{References}

1. Coulibaly ND and Yameogo KR (2000) Prevalence and control of zoonotic diseases: collaboration between Public Health Workers and Veterinarians in Burkina Faso. Acta Tropica 76: 53-7.

2. Applebaum GD and Mathsen G (1997) Spinal brucellosis in a Southern California resident. Western Journal of Medicine 166: 61-65.

3. Arimi SM, Koroti E, Kang'ethe EK, Omore AO, McDermott JJ (2005) Risk of infection with Brucella abortus and Escherichia coli $\mathrm{O} 157: \mathrm{H} 7$ associated with marketing of unpasteurized milk in Kenya. Acta Tropica 96: $1-8$

4. Miller MA and Paige JC (1998) Other food borne infections. Veterinary clinics of North America- Food Animal Practice 14: 71-89.

5. McDermott JJ, Arimi SM (2002) Brucellosis in Sub-Saharan Africa: Epidemiology, control and impact. Veterinary Microbiology 90: 111-134

6. Ojoo J, Amir M and Selcon J B et al. (1995) Serological response to Brucellosis in HIV-seropositive patients. Transactions of the Royal Society of Tropical Medicine \& Hygiene 89: 228-30.

7. Musyoka R (2003) Informal Land Delivery Processes Eldoret Kenya; Summary of Findings and Policy Implications

8. Collins CH, Lyne PM (1995) Microbiological methods $7^{\text {th }}$ ed: $330-332$

9. Leclerc V, Dufour B, Lombard B, Gouchard F et al. (2002) Pathogens in meat and milk products: Surveillance and impact on human health in France. Livestock Production Science 76: 195-202.

10. Mosayebi Z, Movahedian AH, Ghayomi A, Kazemi B (2004) Congenital Brucellosis in a Preterm Neonate. Department of Pediatrics, Shahid Beheshti Hospital, Kashan University of Medical Sciences, Kashan, Iran.

11. Abela B (1999) Epidemiology and control of brucellosis in ruminants from 1986 to 1996 in Malta. Revue Science et Technique 18: 648-59.

12. Steele ML, McNab WB, Poppe C, Griffiths MW, et al. (1997) Survey of Ontario bulk tank milk for food-borne pathogens. Journal of Food Protection 60: 1341-1346.

13. Omore AO, MacDermott JJ, Arimi SM, Kang'ethe EK (2004) Analysis of public health risks from consumption of informally marketed milk in Kenya. The Kenya Veterinarian 27: $15-17$

14. Evelyn N, Margaret W (2005) Dairy Industry in Kenya 2005. A report of the Export Processing Zones Authority.
15. Muriuki SMK, Mcdermott JJ, Arimi SM, Mugambi JTM, Wamola IA (1997) Criteria for better detection of brucellosis in the Narok district of Kenya. East African Medical Journal 74: 317-20.

16. Jumba MM, Mirza NB, Mwaura FB (1996) Agglutinins for Brucellae antigens in blood sera of an urban and rural population in Kenya. East African Medical Journal 73: 204206.

17. Rotich JK, Hannan TJ, Smith FE, Bii J, Odero WW, Nguyen VU, Mamlin BW, Einterz RM, Tierney WM (2003) Installing and Implementing a Computer-based Patient Record System in Sub-Saharan Africa: The Mosoriot Medical Record System. J Am Med Inform Assoc 10: 295303.

18. Sultanov GV and Saidov MS (1998) Intra-uterine zoonotic infections in Dagestan-Russia. Zhural Mikrobiologii, Epidemiologii. 4: 33-36.

19. Almuneef MA, Memish ZA, Balkhy HH, Alotaibi B, Algoda S, Abbas M, Alsubaie S (2004) Importance of screening household members of acute brucellosis cases in endemic areas. Cambridge Journal of Epidemiology and Infection 132: 533-540.

20. Kang'ethe EK, Arimi SM, Omore AO, McDermott JJ, Macharia JK, Gitua A (2000) The Prevalence of Antibodies to Brucella abortus in Marketed Milk in Kenya and its Public Health Implications. Smallholder Dairy (Research and Development) Project Research Report.

21. Stack JA and MacMillan AP (2000) Serological Tests in Brucella Serology; manual of Standards, Diagnostic tests and Vaccines; FAO/WHO Collaborating Centre for Reference and research on Brucellosis.

22. Kang'ethe EK, Arimi SM, Omore AO, McDermott JJ, Nduhiu JG, Macharia JK, Githua A (2004) Testing for Antibodies to Brucella abortus in Milk From Consumers and Market Agents in Kenya Using Milk Ring Test and Enzyme Immunoassay. The Kenya Veterinarian 27: 18-21

23. Omore A, Lore T, Staal S, Kutwa J, Ouma R, Arimi S, Kang'ethe E (2005) Addressing the public health and quality concerns towards marketed milk in Kenya. Smallholder Dairy Project Research and Development Report 3; Smallholder Dairy (R\&D) Project.

\section{Corresponding Author}

Dr. Rose Kakai

Maseno University, School of Public Health and Community Development

PO Box 333 - 40105, Maseno, Kenya

Tel.: 254725980935

E-mail: kakairm@yahoo.com

Conflict of interest: No conflict of interest is declared. 